ISSN: 2224-0616

Int. J. Agril. Res. Innov. \& Tech. 6 (1): 34-40, J une, 2016

Available online at http:/ / www.ijarit.webs.com

\title{
PERFORMANCE OF INDIAN SPINACH AND PAPAYA IN LITCHI BASED AGROFORESTRY SYSTEM
}

\section{H. Uddin' ${ }^{1}$ and S. Chowhan2*}

Received 16 March 2016, Revised 03 June 2016, Accepted 21 June 2016, Published online 30 June 2016

\begin{abstract}
An investigation was conducted at Borjona village of Kapasia, Gazipur district during September 2011 to October 2012 to examine the biological performance of Indian spinach and papaya in litchi based agroforestry system. Papaya was planted between two litchi plants in each line and Indian spinach varieties were grown in the inter-space of two lines of litchi plant as well as control (farmer's practice) in May 2012. Yield and yield contributing characters of Indian spinach varieties grown as litchi-papaya based agroforestry system and control did not vary. However, sprout plant ${ }^{-1}$ and sprout weight of Indian spinach varieties grown in litchi-papaya based system were significantly influenced while the other parameters did not vary. Sprout plant ${ }^{-1}$ of KS green (2.97) and local (2.89) variety were identical but higher over KS red variety (2.57). Sprout weight of KS red variety was the highest $(85.80 \mathrm{~g}$ ) while KS green and local variety gave lower and identical sprout weight. Though the yield did not vary among the varieties, KS red gave the highest yield (36.32 tha1) followed by local (34.61 tha-1) and KS green (34.00 tha-1). In case of growth of litchi, plant height and stem diameter increment were 21.39 and $44.94 \%$ over the eleven months observation period. The yield of papaya was quite satisfactory with an average 42 fruits per plant with $23.71 \mathrm{t} \mathrm{ha}^{-1}$. Therefore, in the Litchi-Papaya-Indian spinach based system, Indian spinach varieties could be ranked as KS red $>$ Local $>$ KS green.
\end{abstract}

Keywords: Indian Spinach, Papaya, Litchi Based Agroforestry System

${ }^{1}$ Agriculture and Food Security Program, BRAC, Lalmonirhat, Bangladesh.

${ }^{2}$ Bangladesh Institute of Nuclear Agriculture (BINA), Sub-station, Khagrachari, Bangladesh.

*Corresponding author's email: sushan04@yahoo.com (S. Chowhan)

\section{Introduction}

Trees in and around homesteads, roads, crop fields and in forests play significant role in the livelihood of the people by providing fruit, timber, fuel wood, animal feed and the ecological stability of Bangladesh. With about 153 million people on 14.7 million hectares, Bangladesh is one of the most densely populated countries (Population Reference Bureau, 2012). Fruits and vegetables are the major source of vitamins and minerals of the people of the country. The minimum dietary requirement of fruits and vegetables per day per capita is $85 \mathrm{~g}$ and $220 \mathrm{~g} / \mathrm{head} /$ day whereas the availability is only $60 \mathrm{~g}$ and $80 \mathrm{~g}$, respectively (Roy, 2011). However, due to high price of fruits and vegetables the majority of people cannot afford to buy them. Trees and tree products play an important role in household food security, the most important being in meeting seasonal food needs. The household consumption of fruits like jack fruit, mango, banana, guava, coconut, papaya, etc. from the homestead trees and the cash earned through the sale of fruits and other tree products help the poor farmers to overcome the lean periods. Homestead vegetables are available year round while tree fruits are available during one lean period (Hassan and Mazumdar, 1990). In most of the villages of high elevation and hilly regions, root crops and tubers are also produced under trees and these are extensively used during lean periods. Nutrition supply is also associated with household income, livelihood and poverty. Homestead trees meet the household nutritional requirement to a great extent. Homestead Agroforestry maintains high levels of productivity, stability and equitability. In a country like Bangladesh homestead areas, involve more than three quarters of all Agroforestry issues and consequently the term Agroforestry is invariably associated with homesteads (Khaleque, 1987). Fruit-tree-based Agroforestry involves simultaneous association of annual or perennial crops with perennial fruit trees on the same farm unit. Because of the relatively short juvenile (preproduction) phase of fruit trees, high market value of their products and the contribution of fruits to household dietary needs, fruit-tree-based agroforestry enjoys high popularity among resources limited producers worldwide (Bellow et al., 2008). Most example of fruit-tree-based Agroforestry has developed over long periods in response to interaction between agro ecological conditions, plant diversity and farmer resources and needs. Many of the practice such as jackfruit based system in Madhupur Tract, Date palm and Palmyra palm based system in Faridpur and 
J essore areas, Mango based system in Rajshahi region etc are well cited on the smallholdings of Bangladesh characterized by sub-optional management and subsistence farming conditions (Miah and Ahmed, 2003). These traditional Agroforestry systems have been contributing to the livelihood systems of the rural household of Bangladesh for centuries through providing diversified products (Akter et al., 1990). It is also capable in providing higher economic return even under stress growing conditions prevailing under the upland situations than the other annual crops (Bikash et al., 2008). Moreover, tree plantations improve soil physical, chemical and biological properties through aocretion and decomposition of organic matter through litter fall, and roots decay. Deep and extensive root systems of trees enable them to absorb substantial quantities of nutrients below the rooting zone of crops and transfer them to surface soil (Hartemink et al., 1996). Litchi is a high value fruit and rich source of vitamin and minerals. Establishment of litchi orchard is getting popularity in the central terrace ecosystem of Bangladesh but farmers are not managing litchi orchard scientifically to grow agricultural crops in the under storey of litchi plants. Papaya is also a high value fruit crop and can be grown successfully in the inter space of litchi plants. It would be a very good agroforestry practices if we can successfully grow Indian spinach and papaya in litchi based agroforestry system biologically and economically. Some sporadic research has been done on fruit tree based vegetable production system. But the performance of different Indian spinach and papaya in litchi based agroforestry system is very much limited in Bangladesh. Taking the above factors into consideration, the present study was under taken with the following objectives:

1) To study the growth and yield of Indian spinach and papaya in litchi-papaya-Indian spinach based agroforestry system

2) To observe growth of litchi in litchi-papayaIndian spinach based agroforestry system.

\section{Materials and Methods}

The study was carried out in a one year old litchi orchard at Borjona village under Kapasia thana in Gazipur district from September 2011 to October 2012. First of all a litchi (China-3 variety) orchard was established by transplanting one year old litchi saplings in October 2011 and about one month old papaya (Shahi variety) seedlings were planted between two litchi plants in each line in January 2012. Indian spinach varieties were grown in the inter space of two lines of litchi plant in May 2012. Three Indian spinach varieties (KS Green, KS Red, and local) were grown in the inter space of two lines of litchi and papaya plants. Seeds of Indian spinach were sown on slightly raised beds between lines of litchi and papaya plants. These three varieties were the treatment of the experiment. The experiment was laid out in one factor Randomized Complete Block Design (RCBD) with five replications. Treatments were randomly allotted in each block. In each plot there were 9 rows accommodating 18 plants row 1. The size-of the unit plot was $5.6 \mathrm{~m} \times 4.1 \mathrm{~m}=$ $22.96 \mathrm{~m}^{2}$ and plant to plant and row to row distance was $30 \mathrm{~cm} \times 45 \mathrm{~cm}$ respectively. Data was collected from five representative plants of Indian spinach at 15 days interval starting from 50 to 125 DAS. Data on number of sprout plant ${ }^{-1}$, number of leaves sprout ${ }^{-1}$, length of stem at harvesting, stem diameter at harvesting, yield plot $^{-1}$ and yield (t ha-1) were recorded. For papaya data on plant height, stem diameter, fruit length, fruit diameter and yield were recorded. For litchi, data on plant height and plant diameter were recorded. Stem and plant diameter of papaya and litchi was measured at $30 \mathrm{~cm}$ above from the ground level. Data were statistically analyzed using the Analysis of Variance (ANOVA) technique with the help of computer package MSTATC to examine the significant variation of the results due to different treatments. The mean differences were adjusted by Least Significant Different (LSD) at 5\% level of significance.

\section{Results and Discussion}

\section{Performance of Indian Spinach at 125 DAS}

At 125 DAS the studied parameters of Indian spinach varieties did not vary (Table 1 and Table 2 ) when they were grown in litchi-papaya based agroforestry system except, weight of sprout (Table 2). It was highest in KS red (89.74 g) and lowest in KS green (81.03 g). Sprout weight of local variety was $84.97 \mathrm{~g}$, which was significantly lower than sprout weight of KS red but higher than KS green (Table 2). However, the studied parameters did not vary much between litchipapaya based Agroforestry system and control.

Table 1. Sprout plant ${ }^{-1}$, number of leaves sprout ${ }^{-1}$ and length of sprout of Indian spinach varieties in litchi-papaya based Agroforestry system at 125 DAS

\begin{tabular}{lcccccc}
\hline Variety & \multicolumn{2}{c}{ Sprout plant ${ }^{-1}$} & \multicolumn{2}{c}{ Leaves sprout $^{-1}$} & \multicolumn{2}{c}{ Length of sprout (cm) } \\
& AF system & Control & AF system & Control & AF system & Control \\
\hline KS green & $2.920 \mathrm{a}$ & $3.05 \mathrm{a}$ & $12.08 \mathrm{a}$ & $12.532 \mathrm{a}$ & $30.68 \mathrm{~b}$ & $32.12 \mathrm{a}$ \\
KS red & $2.443 \mathrm{~b}$ & $2.30 \mathrm{~b}$ & $11.78 \mathrm{ab}$ & $10.32 \mathrm{c}$ & $28.67 \mathrm{c}$ & $29.21 \mathrm{~b}$ \\
Local & $2.553 \mathrm{~b}$ & $3.03 \mathrm{a}$ & $11.47 \mathrm{~b}$ & $11.39 \mathrm{~b}$ & $32.11 \mathrm{a}$ & $26.21 \mathrm{c}$ \\
\hline LSD value & 0.2754 & 0.4285 & 0.4770 & 0.9767 & 1.048 & 1.448 \\
\hline CV $(\%)$ & 5.27 & 7.68 & 2.02 & 4.28 & 1.72 & 2.51 \\
\hline
\end{tabular}


Table 2. Diameter of sprout, weight of sprout and yield of Indian spinach varieties in litchi-papaya based Agroforestry system at 125 DAS

\begin{tabular}{lcccccc}
\hline Variety & \multicolumn{2}{c}{ Diameter of sprout $(\mathrm{mm})$} & \multicolumn{2}{c}{ Weight of sprout $(\mathrm{g})$} & \multicolumn{2}{c}{ Yield (t/ha) } \\
& AF system & Control & AF system & Control & AF system & Control \\
\hline KS green & $11.40 \mathrm{a}$ & $12.32 \mathrm{a}$ & $81.03 \mathrm{c}$ & $78.34 \mathrm{c}$ & $5.72 \mathrm{a}$ & $5.94 \mathrm{a}$ \\
KS red & $11.05 \mathrm{a}$ & $10.36 \mathrm{~b}$ & $89.74 \mathrm{a}$ & $92.64 \mathrm{a}$ & $6.33 \mathrm{a}$ & $6.51 \mathrm{a}$ \\
Local & $11.33 \mathrm{a}$ & $9.37 \mathrm{C}$ & $84.97 \mathrm{~b}$ & $86.31 \mathrm{~b}$ & $6.00 \mathrm{a}$ & $6.32 \mathrm{a}$ \\
\hline LSD value & 0.9949 & 0.6535 & 1.146 & 1.244 & 0.6474 & 0.6716 \\
\hline CV (\%) & 4.42 & 3.07 & 0.67 & 0.73 & 5.38 & 5.36 \\
\hline
\end{tabular}

\section{Average Performance of Indian spinach}

Average performance of Indian spinach varieties in litchi-papaya based Agroforestry system showed that sprout plant ${ }^{-1}$ and weight of sprout were significantly influenced while other parameters did not vary (Table 3 and Table 4). Sprout plant ${ }^{-1}$ was highest in KS green (2.97) which was identical to the local variety (2.89) and lowest was observed in KS red. On the other hand, weight of sprout was found highest in KS

Table 3. Average performance of sprout plant ${ }^{-1}$, number of leaves sprout ${ }^{-1}$ and length of sprout of Indian spinach varieties in litchi-papaya based Agroforestry system

\begin{tabular}{lcccccc}
\hline Variety & \multicolumn{2}{c}{ Sprout plant } & \multicolumn{2}{c}{ Leaves sprout $^{-1}$} & \multicolumn{2}{c}{ Length of sprout $(\mathrm{cm})$} \\
& AF system & Control & AF system & Control & AF system & Control \\
\hline KS green & $2.97 \mathrm{a}$ & $2.77 \mathrm{a}$ & $11.54 \mathrm{a}$ & $12.05 \mathrm{a}$ & $32.57 \mathrm{a}$ & $35.72 \mathrm{a}$ \\
KS red & $2.57 \mathrm{a}$ & $2.63 \mathrm{a}$ & $11.75 \mathrm{a}$ & $11.06 \mathrm{~b}$ & $31.89 \mathrm{a}$ & $31.99 \mathrm{~b}$ \\
Local & $2.89 \mathrm{a}$ & $2.98 \mathrm{a}$ & $11.84 \mathrm{a}$ & $11.48 \mathrm{ab}$ & $33.38 \mathrm{a}$ & $34.55 \mathrm{a}$ \\
\hline LSD value & 0.4853 & 0.3518 & 0.9134 & 0.8732 & 1.715 & 1.437 \\
\hline CV $(\%)$ & 8.64 & 6.31 & 3.91 & 3.79 & 2.63 & 2.11 \\
\hline
\end{tabular}

Table 4. Average performance of sprout diameter, weight of sprout and yield of Indian spinach varieties in litchi-papaya based Agroforestry system

\begin{tabular}{lcccccc}
\hline Variety & \multicolumn{2}{c}{ Diameter of sprout $(\mathrm{mm})$} & \multicolumn{2}{c}{ Weight of sprout $(\mathrm{g})$} & \multicolumn{2}{c}{ Yield (t ha $\left.{ }^{-1}\right)$} \\
& AF system & Control & AF system & Control & AF system & Control \\
\hline KS green & $10.20 \mathrm{a}$ & $9.99 \mathrm{a}$ & $80.32 \mathrm{c}$ & $80.75 \mathrm{c}$ & $34.00 \mathrm{~b}$ & $34.41 \mathrm{~b}$ \\
KS red & $10.54 \mathrm{a}$ & $10.48 \mathrm{a}$ & $85.80 \mathrm{a}$ & $88.62 \mathrm{a}$ & $36.32 \mathrm{a}$ & $37.25 \mathrm{a}$ \\
Local & $10.63 \mathrm{a}$ & $9.83 \mathrm{a}$ & $81.75 \mathrm{~b}$ & $83.32 \mathrm{~b}$ & $34.61 \mathrm{~b}$ & $36.22 \mathrm{a}$ \\
\hline LSD value & 0.8640 & 1.763 & 0.9582 & 2.540 & 1.546 & 1.610 \\
\hline CV $(\%)$ & 4.13 & 8.74 & 0.58 & 1.51 & 2.21 & 2.24 \\
\hline
\end{tabular}

Response of different parameter of Indian spinach varieties on harvesting dates

\section{Number of sprouts plant ${ }^{-1}$}

At 80 and 110 DAS, the highest number of sprouts plant ${ }^{-1}$ was found (Fig. 1.). The variation of sprout number of Indian spinach varieties grown in litchi-papaya based Agroforestry system and control did not vary at all. The reason may be the age of litchi plants. As the experiment was conducted in a one year old litchi orchard so there may be very minimum competition between litchi and Indian spinach plant.

\section{Length of sprout}

Length of sprout recorded in 95 DAS was a bit higher than the other harvesting dates (Fig. 2.). red $(85.80 \mathrm{~g})$, while KS green and local variety produced identical weight (Table 4). Though the yield did not vary among the varieties but KS red gave the highest yield (36.32 $\mathrm{t} \mathrm{ha}^{-1}$ ) followed by local (34.61 t ha-1) and KS green (34.00 t ha-1) variety. The studied parameters of Indian spinach varieties did not vary much between litchi-papaya based system and control.
The reason of such variation is not clear. The variation of sprout length of Indian spinach varieties grown in litchi-papaya based Agroforestry system and control did not vary too much.

\section{Sprout diameter}

Diameter of sprout increased slightly with the harvesting dates. Starting from 80 DAS, it continued up to final harvest (Fig. 3.). This was may be due to the root system of Indian spinach. At the later stage of harvesting, well established root system may uptake more nutrients and water; which facilitate higher sprout diameter. Although, distribution of root system of Indian spinach was not studied. 


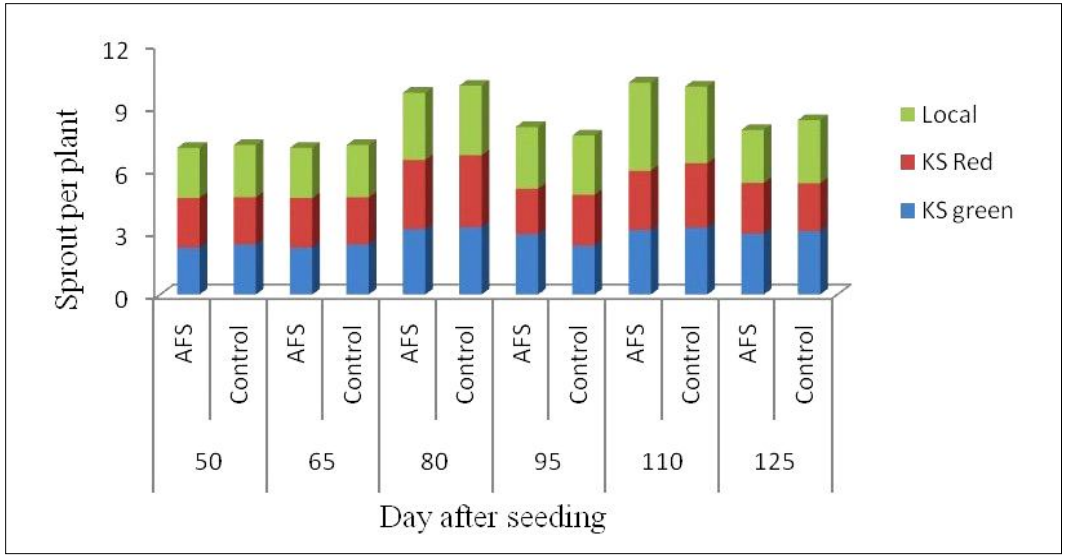

Fig. 1. Response of different Indian spinach varieties on sprout plant ${ }^{-1}$ at different DAS

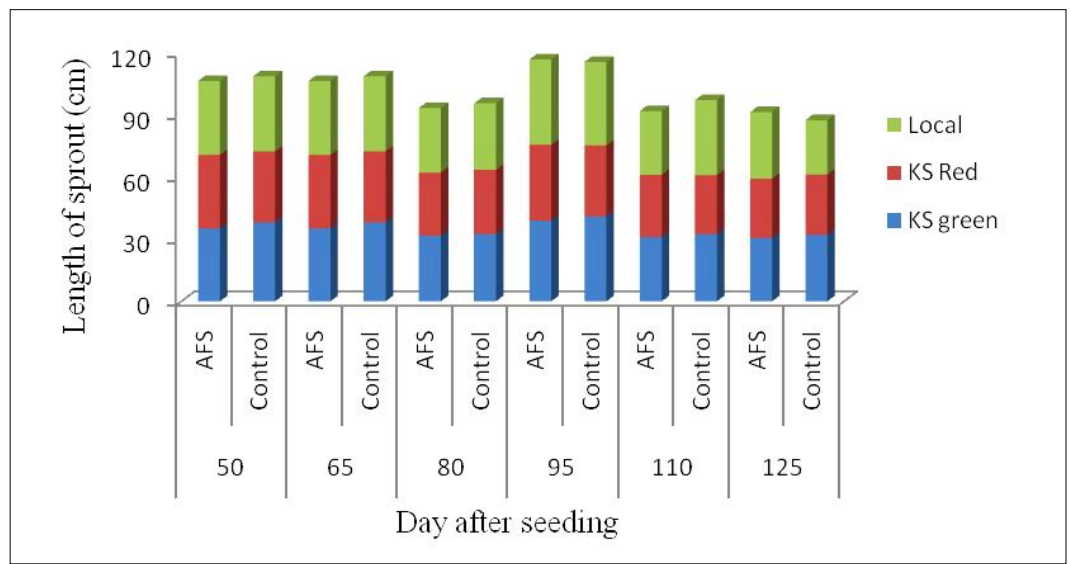

Fig. 2. Response of different Indian spinach varieties on length of sprout at different DAS

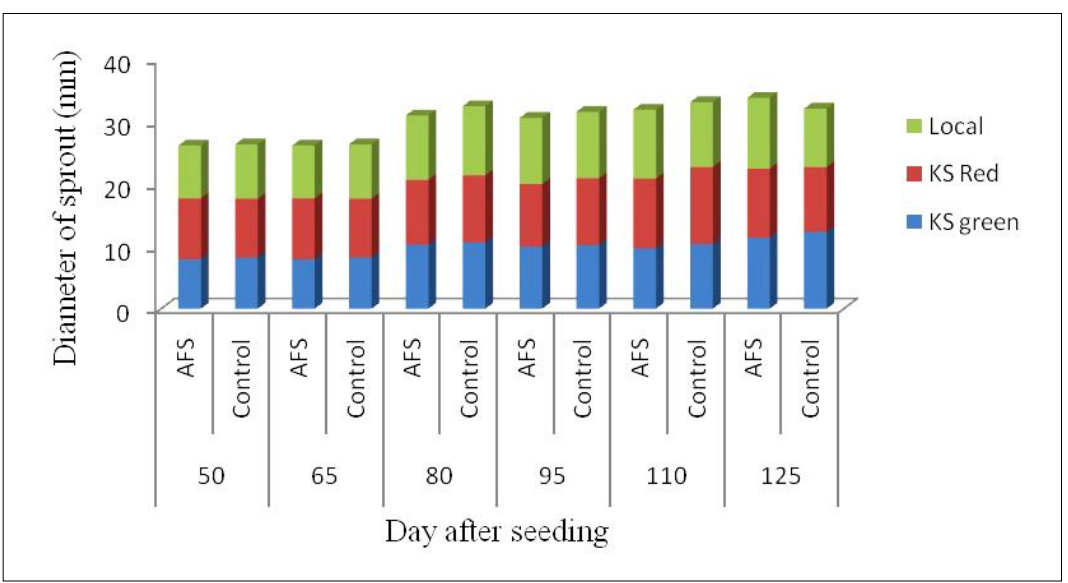

Fig. 3. Response of different Indian spinach varieties on diameter of sprout at different DAS 


\section{Plant height and stem diameter of papaya}

Compatibility between different components of agroforestry depends on the growth stage because of shade effect and root competition (Prasad et al., 2010). The performance of papaya plant was so good under agroforestry on this multistory system. In this mixed Agroforestry system papaya growth and development was smooth without any hamper. Because, there was no lack of nutrient and water as well as minimum competition with young litchi tree. However, this system increased organic matter by leaf litter's falling of vegetables,

Indian spinach and fruit tree litchi. Plant height $(\mathrm{cm})$ and stem diameter $(\mathrm{mm})$ of papaya plant from February to October 2012 has been presented in Fig. 4 and Fig. 5 The plant height and stem diameter were measured in each month. Results showed that the average plant height in February was $27.2 \mathrm{~cm}$ and stem diameter was 11.5 $\mathrm{mm}$ and it increased gradually in each measurement dates and the final plant height and stem diameter in October were $274 \mathrm{~cm}$ and 87.7 $\mathrm{mm}$, respectively.

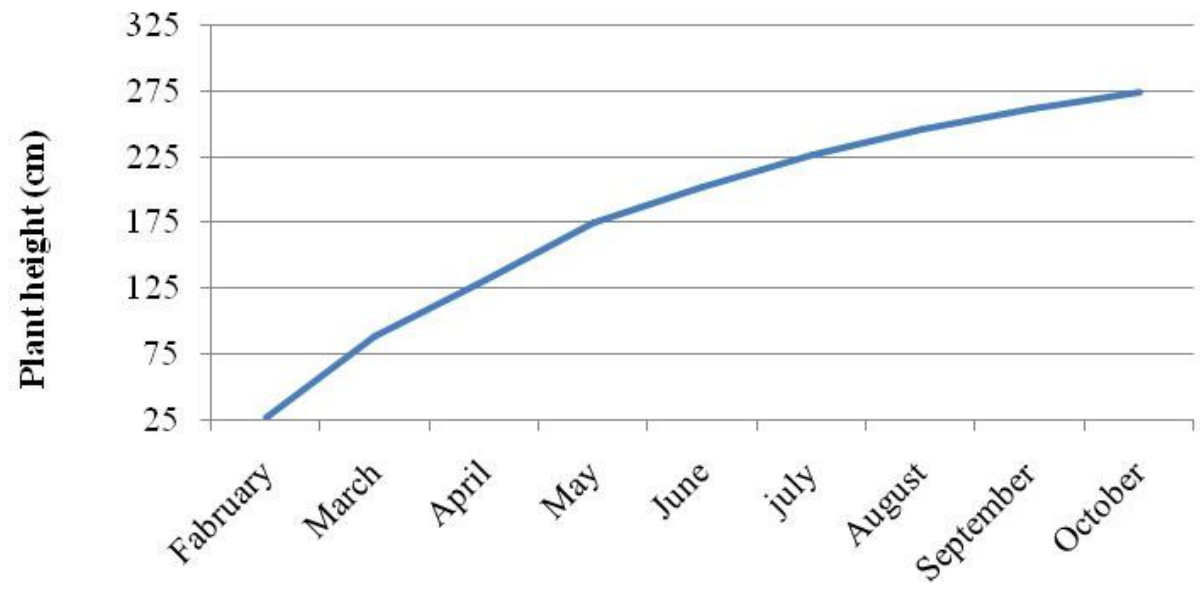

Month of observation

Fig. 4. Plant height of papaya (cm) during February to October 2012

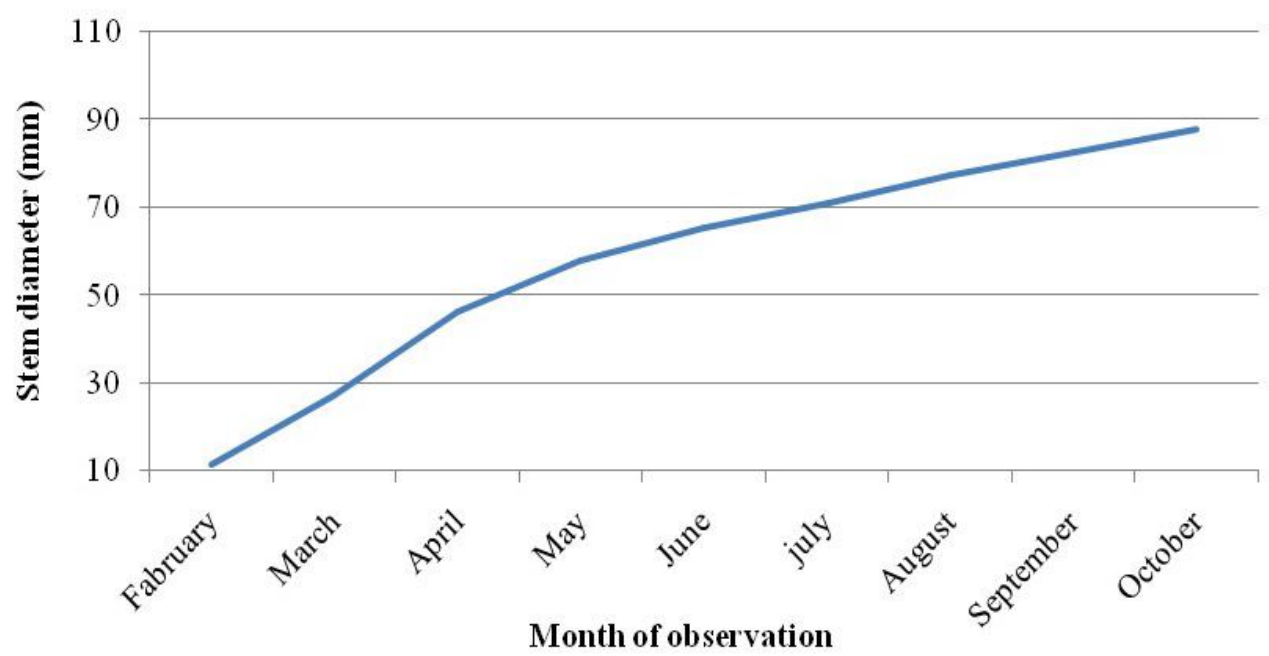

Fig. 5. Stem diameter of papaya (mm) during February to October 2012 


\section{Yield of papaya}

It was found that average fruit number plant ${ }^{1}$ was 42 while the average fruit length, fruit diameter and individual weight were $29.82 \mathrm{~cm}$, $352.18 \mathrm{~mm}$ and $1645.55 \mathrm{~g}$, respectively. Average yield of papaya in litchi-papaya-Indian spinach based Agroforestry system was 23.71 t ha $^{-1}$ (Table 5).

Table 5. Average yield and yield contributing characters of papaya in litchi-papaya-Indian spinach based Agroforestry system

\begin{tabular}{lccccc}
\hline Repl. & Fruit plant ${ }^{-1}$ & $\begin{array}{c}\text { Fruit Length } \\
(\mathrm{cm})\end{array}$ & $\begin{array}{c}\text { Fruit diameter } \\
(\mathrm{mm})\end{array}$ & $\begin{array}{c}\text { Individual Fruit } \\
\text { Weight }(\mathrm{g})\end{array}$ & $\begin{array}{c}\text { Yield } \\
\text { (t ha }^{-1} \text { ) }\end{array}$ \\
\hline R1 & 50 & 33.93 & 325.85 & 1640.96 & 28.14 \\
R2 & 42 & 29.09 & 282.51 & 1702.85 & 24.53 \\
R3 & 45 & 41.81 & 378.67 & 1626.13 & 25.10 \\
R4 & 38 & 40.14 & 388.57 & 1659.02 & 21.62 \\
R5 & 35 & 34.15 & 385.34 & 1599.01 & 19.20 \\
\hline Average & 42 & 35.82 & 352.19 & 1645.59 & 23.72 \\
\hline
\end{tabular}

\section{Tree performance of litchi}

Plant height $(\mathrm{cm})$ and stem diameter $(\mathrm{mm})$ was monitored in each month from December 2011 to October 2012 (Fig. 5 and Fig. 6). In the initial measurement at December 2011 plant height and stem diameter were $88.8 \mathrm{~cm}$ and $8.9 \mathrm{~mm}$, respectively. It increased over time and at final measurement date in October 2012, the plant height and stem diameter were $107.8 \mathrm{~cm}$ and 12.9 $\mathrm{mm}$. Growth performance of litchi tree was found slow. It may take time to develop its root system; on the other hand, litchi is normally a slow growing plant. These were the reasons behind slower growth of litchi plant in litchi-papayaindian spinach based Agroforestry system. The average height and stem diameter increment of litchi plant were 21.39 and $44.94 \%$ over the ten month observation.

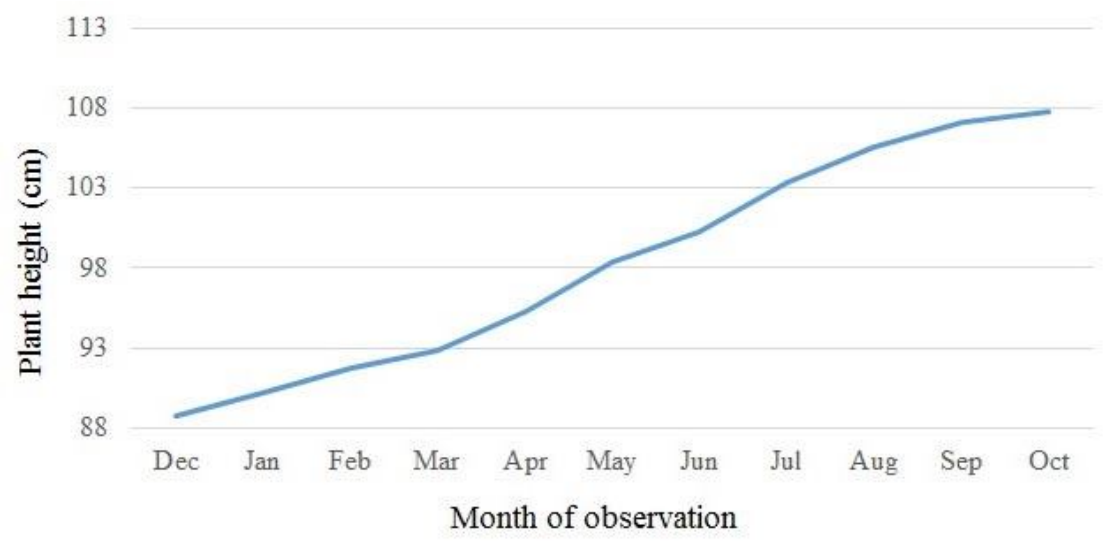

Fig. 6. Plant height of litchi (cm) during December 2011 to October 2012

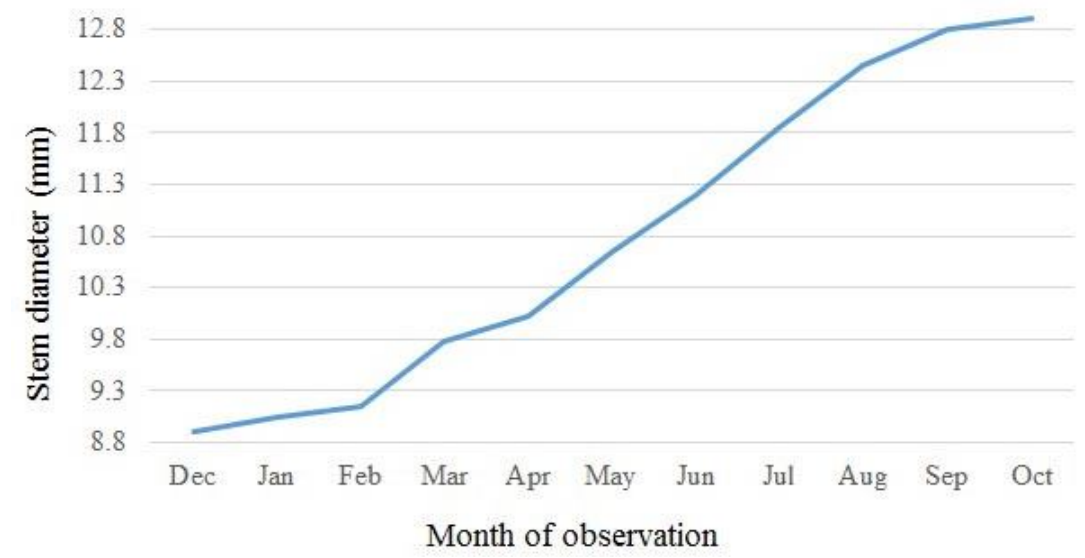

Fig. 7. Stem diameter of litchi (mm) during December 2011 to October 2012 


\section{Conclusions}

The findings from the investigation stated that, yield and yield contributing characters of Indian spinach varieties between litchi-papaya based system and control does not vary much. In litchipapaya based system, the tested three indian spinach varieties responded differently. Sprout plant $^{-1}$ and sprout weight were significantly influenced system while the other parameters did not vary. Though the yield did not vary among the varieties, KS red gave the highest yield $(36.32 \mathrm{t}$ $\mathrm{ha}^{-1}$ ) followed by local (34.61 $\mathrm{tha}^{-1}$ ) and KS green (34.00 t ha-1). The plant height and stem diameter increment of litchi plant were 21.39 and $44.94 \%$ over the initial in ten months observation period and production of papaya was satisfactory with an average of 42 fruits plant ${ }^{-1}$ with $23.71 \mathrm{t} \mathrm{ha}^{-1}$ yields. Regarding selection of Indian spinach varieties it could be ranked as KS red $>$ Local $>$ KS green.

\section{References}

Akter, M.S., Abedin, M.Z and Quddus, M.A. 1990. Why farmer grow trees in agricultural fields; some results. Proc. Regional Symposium on Tree Plantation in the Humid/Sub-humid Tropics in Asia; held on May 5-9, 1998 in University Partanian, Malaysia, and tree in the Sahel. Agroforestry Today 7(1): 9-11.

Bellow, G., Hudson, R.F. and Nair, P.K.R. 2008. Adoption potential of fruit-tree-based agroforestry on small farms in the subtropical highlands. Agroforestry System 73: 23-36.

Bikash, D., Ranvir, S. and Kumar, S. 2008. Fruittree-based agroforestry system for uplands.
Horticultural and Agroforestry research Programme. ICAR Research Complex for Eastern Region Ranchi, Jharkhand, India. pp. 5-97.

Hartemink, A.E., Buresh, R.J., Jama, B. and Janssen, B.H. 1996. Soil nitrate and water dynamica in sesbania fallows, weed fallows and maize. Soil Sci. Soc. Am. J. 60: 568-57.

Hassan, M.M. and Mazumdar, A.H. 1990. An exploratory survey of trees on homestead and wasteland of Bangladesh. ADAB News, March-April 1990.pp. 26-32.

Khaleque, K. 1987. Homestead forestry practices in Bangladesh. Agroforestry for rural needs. Proceedings of the workshop of the IUFRO project group, India. pp. 195-202.

Miah, M.G. and Ahmed, M.M. 2003. Traditional agroforestry in Bangladesh: Livelihood activities of the rural households. A poster presented at the XII world forestry congress, held in September 2003, Canada. pp. 1-78.

Population Reference Bureau. 2012. (Available on line at http://www.prb.org/ pdf12/2012population-data-sheet_eng.pdf). Retrieved on, 26/01/ 2013.

Prasad, J.V.N.S., Korwar, G.R., Rao, K.V., Srinivas, K., Rama, Rao, C.A., SrinivasCh, Venkateswarlu, B., Rao, S.N. and Kulkarni, H.D. 2010. Effect of modification of tree density and geometry on intercrop yields and economic returns in Leucaena based agroforestry systems for wood production in Andhra Pradesh, Southern India. Exp. Agric. 46 (2): 155-172.

Roy, A. 2011. "Requirement of vegetables and fruit" The Daily Star (A English Newspaper). 24/03/2011. 